1 Docherty AJP, O'Connell J, Crabbe T, Angal S, Murphy G. The matrix metalloproteinases and their natural inhibitors: prospects for treating degenerative tissue diseases. Tibtech 1992;10: 200-7.

2 Nagase H, Barratt AJ, Woessner JF Jr. Nomenclature and glossary of the matric metalloproteinases. Matrix 1992;1:421-4.

3 Hasty KA, Fourmotabbed TD, Goldberg GI, Thompson JP, Spinella DG, Stevens RM, et al. Complete structure of the gene for $92-\mathrm{kDa}$ type IV collagenase. Divergent regulation of expression for the 92 and 72 kilodalton enzyme genes in HT-1080 cells. $f$ Biol Chem 1990;265:11421-4.

4 Huhtala P, Tuuttila A, Chow LT, Lohi J, Keski-Oja J, Tryggvason K. Complete structure of the human gene for $92 \mathrm{kDA}$ type IV collagenase. Divergent regulation of expression for the 92 and 72 kilodalton enzyme genes in HT-1080 cells. F Biol Chem 1991;266:16485-90.

5 Basset P, Bellocq JP, Wolf C, Stoll I, Hutin P, Limacher JM, et al. A novel metalloproteinase gene specifically expressed in stromal cells of breast cancer. Nature 1990;348:699-704.

6 Docherty AJ, Lyons A, Smith BJ, Wright EM, Stephens PE, Harris TJ, et al. Sequence of human tissue inhibitor of metalloproteinases and its identity to erythroid-potentiating activity. Nature 1988;318:66-9.

7 Boone TC, Johnson MJ, DeClerck YA, Langley KE. cDNA closing and expression of a metalloproteinase inhibitor related to tissue inhibitor of metalloproteinases. Proc Natl Acad Sci USA 1990;87:2800-4.

8 Angel P, Imagaw M, Chiu R, Stein B, Imbra RJ, Rahmsdorf HJ, et al. Phorbol ester-inducible genes contain a common cis element recognised by a TPA-modulated trans-acting factor. Cell 1982;49:729-39.

9 Matrisian LM, McDonnell S, Miller DB, Navre M, Seftor EA, Hendrix MJ. The role of the matrix metalloproteinase stromelysin in the progression of squamous cell carcinoma. Am $\mathcal{f} \mathrm{Med} \mathrm{Sci}$ 1991;302:157-62.

10 Takemura M, Azuma C, Kimura T, Tokugawa Y, Miki M, Ono M, et al. Malignant cell-specific gelatinase activity in human endometrial carcinoma. Cancer 1992;70:147-51.

11 Campo E, Merino MJ, Tavassoli FA, Charonis AS, Stetler-Stevenson WG, Liotta LA. Evaluation of basement membrane components and the $72 \mathrm{kDa}$ type IV collagenase in serous tumors of the

12 Yoshida K, Tsujino T, Yasui W, Kameda T, Sano T, Nakayama H, et al. Induction of growth factor-receptor and metalloproteinase genes by epidermal growth factor and/or transforming growth factor-alpha in human gastric carcinoma cell line MKN-28. Ipn f Cancer Res 1990;81:793-8.
13 Hewitt RE, Leach IH, Powe DG, Clark IM, Cawston TE, Turner DR. Distribution of collagenase and tissue inhibitor of metalloproteinases (TIMP) in colorectal tumours. Int $\mathcal{f}$ Cancer 1991;49:666-72.

14 Stearns ME, Wang M. Regulation of kinesin expression and type IV collagenase secretion in invasive human prostate PC-3 tumor sublines. Cancer Res 1991;51:5866-75.

5 D'Errico A, Garbisa S, Liotta LA, Castonovo V, Stetler-Stevenson WG, Grigioni WF. Augmentation of type IV collagenase, laminin receptor, and Ki67 proliferation antigen associated with human colon, gastric and breast carcinoma progression. Mod Pathol 1991;4:239-46.

16 Momiki S, Baba M, Caamano J, Tizasa T, Nakajima M, Yamaguchi Y, et al. In vivo and in vitro invasiveness of human lung carcinoma cell lines. Invasion Metastasis 1991;11:66-75.

17 Polette M, Clavel C, Muller D, Abecassis J, Binninger I, Birembaut P. Detection of mRNA's encoding collagenase 1 and stromelysin 2 in carcinomas of the head and neck. Invasion Metastasis encoding collagen

18 Cottam DW, Rennie IG, Woods K, Parson MA, Bunning RA, Rees RC. Gelatinolytic metalloproteinase secretion patterns in ocular melanoma. Invest Opthalmol Vis Sci 1922;33: 1923-7.

19 Akeli MG, Madoulet C, Rallet A, Jardillier JC. Inhibition of collagenolytic activity in human leukemic K562 cells by tamoxifen. Leuk Res 1991;15:1153-7.

20 Lu X, Levy M, Weinstein IB, Santella RM. Immunological quantitation of metalloproteinases in metastatic tumor cells leading to increased levels of collagenase activity. Cancer Res 1991;51: 2138-43.

21 Ponton A, Coulombe B, Skup D. Decreased expression of tissue inhibitor of metalloproteinases in metastatic tumor cells leading to increased levels of collagenase activity. Cancer Res 1991;51: $2138-43$

22 Melchiori A, Albini A, Ray JM, Stetler-Stevenson WG. Inhibition of tumor cell invasion by a highly conserved peptide sequence from the matrix metalloproteinase enzyme prosegment. Cancer Res 1992;52:2353-6.

23 Khokka R, Waterhouse P, Lala P, Zimmer M, Denhardt DT. Increased proteinase expression during tumor progression of tissue inhibitor of metalloproteinases cell lines down-modulated for levels: a new transformation paradigm? I Cancer Res Clin Oncol 1991;117:333-8.

24 DeClerck YA, Perez N, Shimada H, Boone TC, Langley KE, Taylor SM. Inhibition of invasion and metastasis in cells transfected with an inhibitor of metalloproteinases. Cancer Res 1992;52:701-8.

\title{
The consultant episode: an unhelpful measure
}

\author{
Time to replace it with a single episode of disease?
}

Inpatient activity in the NHS is increasing steadily. But although the number of completed consultant episodes has increased, we don't know what this means in terms of actual health care delivered. ${ }^{12}$ The advent of the internal market makes it even more important that we find out.

Consultant episodes, which record occasions on which an inpatient is under the care of a consultant, were devised before the advent of the purchaser-provider split, primarily as a way of examining resource use in hospitals. ${ }^{3}$ They give no indication of numbers of admissions to hospitals, let alone the actual numbers of patients being treated, ${ }^{4}$ and are increasingly being regarded as lacking in clinical and epidemiological coherence. Measuring activity in terms of hospital episodes results in the possibilities for opportunism by providers and gives rise to potentially important perverse incentives within the internal market.

Previously, a disease was often diagnosed and treated in the course of a single admission. Increasingly this process takes place during a series of admissions, sometimes because pressure on beds precludes keeping patients in hospital (for example, while a series of tests are awaited), or because treatments such as chemotherapy require a series of admissions. Ferguson et al calculated that increasing numbers of multiple admissions accounted for one third of the increase in ophthalmological admissions in the Oxford region between 1975 and $1985 .{ }^{6}$ Furthermore, increasing specialisation may lead to transfer of a patient's care from one consultant to another. This may occur when one consultant provides initial management and another provides less acute care or when a generalist makes an initial diagnosis and then transfers the patient to a specialist for a particular treatment, currently resulting in an increase in the recorded number of consultant episodes.

Several ways exist for providers to play this system to maximise their income without increasing their work. These include increasing the frequency with which patients are transferred between consultants during a hospital stay and staggering a series of investigations. The potential for "admission splitting" was recognised with the introduction of prospective payment in the United States, ${ }^{7}$ and the Health Care Financing Administration initiated programmes to counter it. ${ }^{8}$ Although total admissions fell, the programmes have been less successful with certain patient groups. One phenomenon, known as "unbundling," entails admitting and discharging patients with multiple diseases several times, each time allocating a different principal diagnosis. ${ }^{9}$ Providers now describe this explicitly as a way to maximise their income. ${ }^{10}$ Currently in Britain working the system like this would probably not affect overall costs, but it could certainly seriously distort patterns of contracts for purchasers.

One solution might be to regard all episodes within a fixed time frame as a single episode of disease. But this would unfairly disadvantage providers in some cases - transfers or readmissions soon after discharge may be due to a completely different condition. ${ }^{112}$ One way forward would be to identify all consultant episodes undergone by a patient and then to differentiate, on clinical grounds, those that are related to the index episode from independent episodes. ${ }^{13} \mathrm{~A}$ single episode of disease might include a planned course of treatment requiring several admissions. For example, a diabetic patient may be admitted to hospital nine times over two years. Examination of the diagnoses and procedures may show that three closely spaced episodes were for laser photocoagulation, three were for surgical treatment of peripheral vascular disease and subsequent wound infection, and three were for hyperglycaemia. This pattern could be considered to represent one episode of treatment for diabetic eye disease, one for diabetic vascular disease, and three for hyperglycaemia - that is, five episodes of disease rather than nine. A patient with cancer could be regarded as having an initial episode of disease in which admissions were for diagnosis and surgical treatment, a second episode with multiple admissions for chemotherapy, and a final episode for palliative care. This example, 
in which the "purpose of admission" is considered to be an explanatory variable, has been found to increase the predictive power of formulas used to compare resource consumption and outcome in the United States. ${ }^{14}$

The first step in this process is to describe what is currently happening. Purchasers need more information on the packages of care provided for the population for whom they are responsible. Panels of clinicians could advise on which of the commonly observed patterns of multiple admissions should properly be regarded as a single episode (as in the example of diabetes given above) and generate rules for use with routine hospital information systems. The absence of a unique NHS patient identifier remains a problem, although this is less important if readmissions to a single provider are being considered, as the same hospital number will normally be used for each patient. Existing information systems containing diagnostic data cover only inpatient and day surgery. In future, defining packages of care that include outpatient treatment will be necessary, particularly because patients with chronic disease are receiving more of their care in the community.

The contracting process is in its infancy; purchasers are negotiating multimillion pound contracts on the basis of totally inadequate information, and improving health through the contracting process is still a long way off. But the key position of the consultant episode in the contracting process and the possibility for opportunism by less scrupulous providers make it essential to consider more clinically and epidemiologically relevant alternatives for describing health care and provider activity.

We are grateful to Hugh Sanderson and Francesco Taroni for their comments.

AILEEN CLARKE

Honorary Lecturer

MARTIN MCKEE Senior Lecturer

Health Services Research Unit,

London School of Hygiene and Tropical Medicine,

London WC1E 7HT

1 NHS Management Executive. The NHS reforms; the first six months. London: HMSO, 1992.

2 Radical Statistics Health Group. NHS reforms: the first six months - proof of progress or a statistical smokescreen? BMF 1992;304:705-9.

3 GB Steering Group on Health Services Information. First report to the secretary of state. London: HMSO, 1984. (Chair: Mrs E Körner.)

4 Goldacre MJ, Simmons H, Henderson J, Gill LE. Trends in episode based and person based rate of admission to hospital in the Oxford record linkage study area. BMF 1988;296:583-5.

Clarke A, Tinsley P. Completed consultant episodes and hospital discharge. BMf 1992;304: 987.

6 Ferguson JA, Goldacre MJ, Henderson J, Bron AJ. Ophthalmology in the Oxford region: analysis of time trends from regional statistics. Eye 1991;5:379-84.

Con BB, Pokras R, Meads MS, Krushat WM. How will diagnosis-related groups affect epidemiological research? Am $\mathcal{F}$ E pidemiol 1987;126:1-9.

Russell LB, Manning CL. The effect of prospective payment on Medicare expenditures. $N$ Englf Med 1989;320:439-44.

Gay EG, Kronenfield JJ. Regulation, retrenchment-the DRG experience: problems from changing reimbursement practice. Soc Sci Med 1990;31:1108-18.

10 Zuckerman AM. The impact of DRG reimbursement on strategic planning. Hospital and Health Sciences Administration 1984;29:40-9.

11 Milne RIG, Clarke A. Can readmission rates be used as an outcome indicator? BMF 1990;301: $1139-40$.

12 Clarke A. Are readmissions avoidable? BMF 1990;301:1136-8.

13 Chambers M, Clarke A. Measuring readmission rates. BMF 1990;301:1134-6.

14 Iezzoni LI, Henderson MG, Bergman A, Drews RE. Purpose of admission and resource use during cancer hospitalisation. Health Care Financing Review 1991:13:29-40.

\section{Whistle blowing: a curse on ineffective organisations}

\section{Better management, not gagging, is the answer}

Competent managers have nothing to fear from whistle blowing. They have no reason to write clauses into employees' contracts forbidding them to talk to the media. Indeed, such gagging clauses are highly likely to create the conflict that managers are trying to avoid. Rather than wasting time trying to gag staff, managers should be concentrating their energies on creating organisations where whistle blowing and gagging are both irrelevant.

One of the best analysed episodes of whistle blowing began in February 1991 when a doctor at the Christie Hospital went to the media about a woman with renal cell carcinoma who was denied treatment with interleukin 2-supposedly on grounds of cost. ${ }^{1}$ Huge publicity resulted, and the woman was eventually given the drug. An inquiry conducted by Michael Orme, professor of clinical pharmacology in Liverpool, concluded, however, that the publicity was "almost totally counterproductive": staff and patients lost confidence in the hospital; some patients were worried that they had not got the treatment they should have had on grounds of cost; and fund raising was made more difficult. ${ }^{2}$

The background to the story was that interleukin 2 had no product licence, and its usefulness in renal cell carcinoma was still unclear. The drug's use had been considered by the hospital's drug and therapeutics committee, but the oncologists, it emerged, had no faith in the committee. Most of Professor Orme's recommendations related to improving the decision making mechanisms within the hospital. The episode showed that management by media is hopeless.

Most organisations eventually have to take tough decisions. Difficult choices, particularly over allocating resources, have long been part of working in the NHS. The choices will become tougher, and there may be more losers than winners. The fear that the losers will tell all to the media is what leads managers to reach for their gags. They make a mistake. Instead, they need to create organisations - be they hospitals or health authorities - where employees feel enough part of the decision making process not to need to blow their whistles.

You begin by letting everybody know what is going on. If the rhetoric is glossy brochures full of the word "quality" and the reality is elderly patients with pressure sores in back wards with peeling paint, then staff will become cynical and demotivated. They need to be convinced that the available resources are used fairly, efficiently, and effectively. The surest way to convince them is to involve them in decision making. The decisions that are made must be clearly and honestly communicated. Staff must have a chance to come back on poor decisions, and managers should not be afraid to reverse decisions that are wrong.

If staff understand the true circumstances of the organisation and feel that their views have been given serious attention then they will accept tough decisions. But if seemingly arbitrary decisions appear from nowhere then staff will be unhappy and one or two will contact the press. Managers who try to create a climate of fear will neither stop whistle blowing nor run an effective health service. Managers also have a broader responsibility to their local communities, and being honest with the local media is no less important than being honest to staff. A long term relationship with local journalists that includes discussing difficulties will produce much richer returns than a cloud of obfuscation and a brisk "No comment" after somebody has blown the whistle. Letting arguments be 